\title{
The Moral Panic of Environmental Crime in the Geothermal Exploration Project in Banyumas
}

\author{
Arif Awaludin ${ }^{1, *}$ \\ ${ }^{1}$ Faculty of Law, Wijayakusuma University, Purwokerto, Indonesia
}

\begin{abstract}
The project of natural gas exploration inflicts sufferings on the population living in the area of Mount Slamet at Banyumas Regency. This paper examines how the media coverage relating to the environmental crime signals of the geothermal exploration activities in Baturaden, creates a moral panic in the area. This study establishes the signals of environmental crime that contributes to the emergence of moral panic in the society. It also discusses the moral panic of the public manifestation as a response to a significant social anxiety. A qualitative approach is used in this study. This study reveals that the existence of public moral panic towards the activities of natural gas exploration in Mount Slamet results in the development of an environmental crime signal and the emergence of moral panic. This moral panic triggers various events and social reactions which call for the enforcement of legislation against the performers of environmental crimes.
\end{abstract}

\section{Introduction and Literature Review}

Mount Slamet is the highest mountain in Central Java; it is encircled by five districts in Indonesia (namely Banyumas, Purbalingga, Pemalang, Tegal and Brebes). The southern slope of Mount Slamet (which belongs to the administrative area of Banyumas Regency) is a protected and well-maintained ecosystem with green trees and wide diversity of protected animals. Mount Slamet is a major source of water for the Banyumas Regency because it has big rivers such as Banjaran, Gumawang and Logawa. These rivers are the largest water located in Banyumas. This is the only mountain with a large bio-diversity in western Central Java [1]. However, the construction of Geothermal Power Plants (PLTPB) in the southern slope poses major threats to its ecosystem [2]. This construction may result in a shift in the ecosystem; some of the living organisms that might be affected include birds and primates such as monkeys, apes and lemurs.

The presence of PT Sejahtera Alam Energy (SAE) which will build a Geothermal Power Plant (PLTPB) in Baturrden has created a moral panic in Central Java. This is reflected in the disapproval of activities that may result in any adverse environmental impacts and the social reactions of the inhabitants of the district. This moral panic may be an indication of perceived environmental crime as a result in the command of the geothermal exploration activities at Mount Slamet, Baturaden.

\footnotetext{
*Corresponding author: arifawaludin@gmail.com
} 


\subsection{Moral Panic}

Moral panic is a term introduced by Stanley Cohen in 1966; Cohen (1966) reflects on the conceptual status of moral panic and its influence on the study of social reactions to crime. The author explains that moral panic is not only identified by the cause of events, but by other deep implications. The term panic can be defined as an intense and debilitating reaction period that does not last long or it can be permanently. Moral panic tries to explain certain types of overreaction to perceive social problems. This began to develop in the rise of political and intellectual contexts in the late 1960s. The main objective is to expose the processes involved in the creation of concerns about social problems [3]. There are three main issues that form the basis of the "moral panic" concept, these include normativity, temporality and unintentionality.

The term 'moral panic' implies that the public's reaction is basically a camouflage prepared by the government to cynically manipulate the media and public agenda. Moral panic is a mechanism for a community to maintain shared values such as decency, politeness amongst others. If there is a deviation, the society uses this mechanism to maintain its values [4].

\subsection{Environmental Crime}

The determination of "environmental crime" is applied to behavior rather than to legal provisions that must be protected both ecologically and physically [5]. Environmental crime is defined by Ridha Saleh, as any behavior, act or omission of the deprivation of the right to environment and source of life of the people who made directly through the influence of capital strength, political strength and power in an enterprise or government. It rises and results in the destruction of the continued advocacy for the environment, the source of people's life, as well as the threats to disruption of human life [6]. Environmental crime is an illegal act that directly harms the environment [7]. The environmental crime has adverse consequences on the security of a country. For individuals and communities, it may have a negative impact on public health, livelihood, property value, non-human species, and the future generation [8].

Extensive environmental crime can be defined as illegal actions that are directly harmful to the environment. These illegal actions include illegal trade in wildlife, smuggling of ozone depleting substances (ODS), illegal trade in hazardous waste, illegal, unregulated, and unreported fishing, and illegal logging as well as related trade in stolen wood products [9]. Environmental crime is the fourth largest crime after drug trafficking, counterfeiting and human trafficking. Environmental crime is not a new threat; this type of crime has become more serious and organized in different parts of the world [10]. Environmental crime in Indonesia is regulated by Law No. 32/2009 on Environmental Protection and Management [11].

The endangerment of flora and fauna species is a widespread environmental crime. Other forms of environmental crime include illegal actions with negative impacts on the different components of the environment (such as water, air, soil, and climate). This is one of reasons why environmental crime is often seen as 'without sacrifice'. Environmental crime increases the risk of disease outbreak, environmental disasters, climate change, food chain contamination, and reduces life expectancy. Many species are on the verge of extinction due to the illegal wildlife trade [12]. The negative impacts of environmental crime on neighborhoods cannot be seen directly because such impacts are the product of an accumulative process. In spite of the threats posed by environmental crime, it is still underestimated by social, economic and political systems. 
Environmental crime is clearly identified as "a rising threat". This is due to the absence of a thorough mindfulness about the seriousness of this crime amongst the public and law enforcement officials [13]. Those involved in environmental crime are motivated by money; they aim to make as much as possible within the shortest time period, with minimum effort, expenditure and risk. Such people do not pay any attention to the environment.

\subsection{Crime Signals}

The term "crime signals" was first stated by Martin Innes in 2004 [14]. His perspective provides an innovative way to meaningfully define and to translate crime as well as disorder in the community. This perspective also helps to describe how the social character of the physical space can be constructed symbolically. Crime signal can be defined as an event that, with a high risk of criminogenicity. Meanwhile, the disorders deviation has two main forms. It depends on denotative expression, both physical and social, and connotes the existence of undesirable risk [15]. From this perspective, not the seriousness of an event (however measured), but the signal value of an event that has the greatest influence. This will be influenced by various factors such as perceptions of seriousness and impact on the individual or environment, frequency, time and location of events, behavioral expectations, and media coverage [16].

Crime signals can be defined as an incident that disproportionately influences individuals to feel they at risk [17]. The research conducted by Roach, Alexander and Pease (2012) confirms the importance of "crime signals" in policy making and crime prevention [18]. Thoughts about signals and signaling opens up new ways to see crime, distractions, and social control. Crime signals have become a major analysis unit to measure the impact of crime in an aggregate form [19].

\section{Purpose of the Study}

This study aims to identify and to investigate the phenomenon of moral panic. This starts from a signal of environmental crime that has evolved into moral panic, until the emergence of law enforcement demands. This study is conducted by examining the media coverage relating to the environmental crime signals of geothermal exploration activities in Baturaden that has created moral panic over time. Mass media has a significant impact on the emergence of moral panic because it frames reality pictures in predictable and patterned ways [20].

\section{Methodology}

A qualitative approach was used in this study. Firstly, the context of the dimensions of environmental crime is established in this study. Secondly, the coverage of the mass media (between the periods of January 2017 to June 2018) about the community's reaction to the geothermal exploration by PT SAE in Baturaden Banyumas is discussed. Thirdly, the extent of threat of the reported crimes served as a basis for the concept analysis of moral panic. This study seeks to highlight how the media presented the news about of environmental crime signals and to describe the emergence of moral panic based on the analysis of environmental crime signals. 


\section{Discussion}

Mount slamet is the highest active volcano in Central Java with a natural tropical forest on the Java island. A variety of flora and fauna live on Mount Slamet; these organisms range from leopards, Javanese eagles, mountain orchids to frog species that have not yet been named in Mount Slamet. All these organisms live on Mount Slamet as the forest is moist and the soil conditions are wet due to the water is uptake from the major rivers in the Mount Slamet. This condition makes Mount Slamet a suitable source of water to the living organisms around the environment. The surrounding community is highly dependent on Mount Slamet for the different life activities such as agriculture, fisheries, forestry and tourism. However, the condition in Mount Slamet has changed instantly after the arrival of the geothermal power development project (PLTP). PLTP is a power plant that utilizes geothermal energy as its energy source [21].

Based on the Decree of the Governor of Central Java, No. 541/27/2011 dated April 11, 2011, PT Sejahtera Alam Energy (SAE) obtained a license to establish a geothermal mining business in the Baturraden area. The project location covers 24,660 hectares (ha) and includes the following districts: Banyumas, Purbalingga, Tegal, Brebes, and Pemalang. The party has secured a borrowing license for protecting forest areas from the Ministry of Forestry to commence the geothermal development on the slopes of Mount Slamet on the 13th August 2012. The area of utilization permit is 44 hectares as a starting point for exploration [22].

Geothermal project activities threaten the balance of the ecosystem in Mount Slamet. The deforestation that is occured in the areas of mountain forest dismantles the massive forests and results in the damage and the pollution of several river channels, including the Logawa river [23]. The rivers that flow through 13 villages in Banyumas experience turbidity due to the contamination of mud [24].

The exploration activities accompanied by desforestation also results in the occurrence of flash floods and landslides, particularly in mountainous areas. After the completion of the exploration phase, the exploitation phase commences. This phase includes two major activities: drilling and electricity production. The impacts of these activities result in the occurrence of a minor earthquake measuring 3.4 to 5 on the Richter scale. The earthquake results in the crack of building and the environmental contamination that generates waste of the geothermal power plant. The toxic substances in the waste include; Arsenic, Antimony and Baron [25]. On the 15th October 2017, flash floods occurred due to the heavy rainfall at the upper area of Mount Slamet's river and slopes. The victims of the flashflood were those who lived around rivers of Banjaran, Pelus, Logawa and Prukut [26]. Currently, hundreds of hectares of the protected forests in the Mount Slamet area have been explored as a result of the Baturaden Geothermal Power Plant (PLTP) project. This has potential to cause environmental damage in the area, including tourist areas that are mostly visited by tourists. Presently, PT SAE has commenced the exploration stage. The total area of protected forest that has been cleared for exploration is 675.7 hectares. Logging activities have also been commenced at the Dringo Park Swamp area and the Bukit Rata Amba. It has resulted in the increasing of deforestation and the reducing of water uptake. The commencement of the exploration phase has resulted in an imbalance of the ecosystem. The animals from Mount Slamet often appear in the villages or the edge of the forest and damage the people's agricultural land. The construction of the Baturaden PLTP has also had an unfavorable impact on the communities which covers the five regencies in Central Java, (these includes Banyumas Regency, Brebes Regency, Tegal Regency, Pemalang Regency and Purbalingga Regency) [27].

The society as a direct victim of the geothermal power project (PLTP) has reacted to the detrimental impact of the commencement of the development plan [28], particularly those who are the residents of Melung Village, Baturaden District, and Bayumas District. The 
escalation of public reaction has also increased. During the Earth Day commemoration, hundreds of students held a demonstration in Purwokerto square demanding the cancellation of geothermal projects. This protest was based on the allegation that PT Sejahtera Alam Energy (SAE) did not have a license of Environmental Impact Analysis (AMDAL). The students also showed 31 photos of the environmental damages caused by the exploration activities [29]. The petition was posted online, as the students asked their community's support and demanded the President to stop the project [30]. The Alliance of Indonesian Farmers in 7 regencies in the vicinity of Mount Slamet also protested against the command of the exploration activities [31]. The pinnacle of the demonstration took place on the 18th July 2017. Hundreds of people from various elements of the society, who are the members of the Save Slamet Alliance occupied the plenary session of the Banyumas DPRD, Central Java [32]. The community demanded that the Banyumas regent revokes the permit for geothermal exploration of PT Sejahtera Alam Energy (SAE). The community considered the construction of PLTP Baturaden as a fatal mistake done by the government [33]. Demonstrations took place again on the 9th October 2017 by the community from 3 subdistricts, namely Sumbang Subdistrict, Karanglewas Subdistrict and Cilongok District. They demanded that the regent revokes PT SAE's exploration permit as it caused the damage to the environment and society [34]. The demonstrations was ended with the violence done by the police; 15 protesters were arrested and beaten by the police. Some police officers also violated 28 people and damaged 2 mobile phones, 2 motorcycles, cars and tents [35]. Many people demanded the completion of violence done by the police officers against the demonstrators. Some journalists who covered the demonstration did not escape as victims. Therefore, the Indonesian Journalist Organization (PWI) and the Alliance of Indonesian Journalists (AJI) also took a stand on the incident [36-37].

Based on the process of the emergence of moral panic in the spiral deviancy amplification model revealed by Cohen [38]. It was seen that the news of the media gave an amplification on various crime signals that occurred when geothermal exploration activities were carried out at Mount Slamet, Baturaden. Moral panic as reported by the news media covered three things: a warning, impact and social reaction. This is shown in the Figure 1:

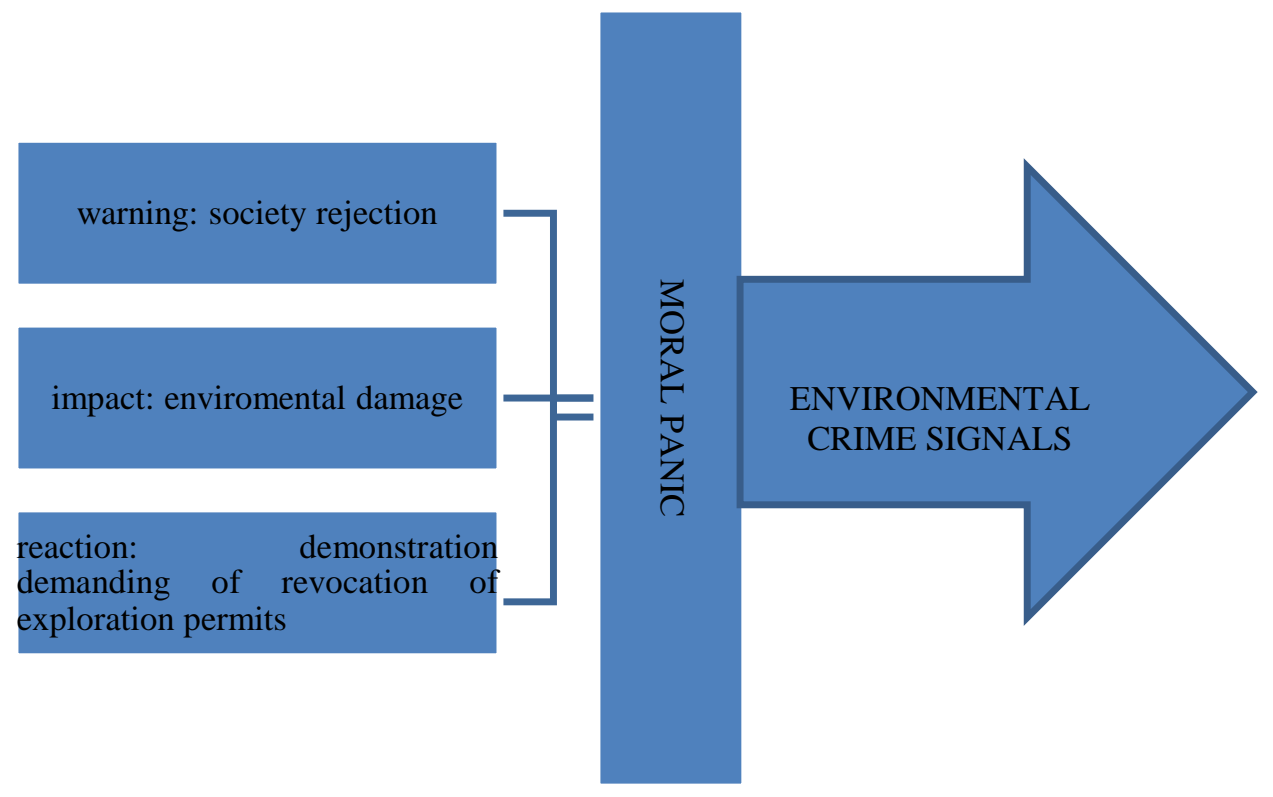

Fig.1. a warning, impact and social reaction 


\section{Conclusion}

The geothermal exploration activities carried out by PT Sejahtera Alam Energi (SAE) in Baturraden received a negative reaction from the people living in Mount Slamet. The geothermal exploration permits owned by PT SAE does not comply with Indonesia's law of environmental management and protection. The various negative impacts caused by the exploration activities damaged the natural environment of Mount Slamet, threaten the security of the people and harmed the society. This resulted in the emergence of the moral panic reported by the media during the periods of 2017 to mid 2018. This moral panic is a sign of environmental crime. It takes attention, cares, and protection for the community and the nature around Mount Slamet, Baturaden. Various laws and regulations on the environmental and geothermal exploration needs to be considered.

\section{Reference}

1. http://revolusitotal.org/gunung-slamet-yang-tak-lagi-selamat/

2. https://www.vebma.com/opini/pembangunan-proyek-pembangkit-listrik-tenaga-panasbumi-di-gunung-slamet/16706\#ixzz5LPaNKd2w

3. Rohlof, Amanda, Wright, Sarah, csi, 58, 3, Pp. 403-419. DOI: 10.1177/0011392110364039 (2010)

4. Eriyanto, Analisis Naratif: Dasar-dasar dan Penerapannya dalam Analisis Teks Berita (Media, Kencana: Jakarta 2013)

5. Clifford, Mary, T. D. Edwards.. "Defining 'Environmental Crime.' "In Environmental Crime: Enforcement, Policy, and Social Responsibility (edited by Mary Clifford. Gaithersburg, Md.: Aspen, 1998)

6. Meliala, A. Eliasta, Bunga Rampai Kriminologi (Fisip UI Press, Depok, 2010)

7. W. R. Korir, Environmental Crime Management In Kenya, (Thesis, University of Nairobi, 2013)

8. M. O`Hear, jclc 95, 1, Pp. 133-276 (2004)

9. M. Rice, Environmental Crime: A threat to Our Future, Environmental Investigation Agency (EIA), ( Editor, London, 2008).

10. A.R. Andriani, Serious and Growing. Environmental Crime Tackling the Greatest Threats to Our Planet, Our Planet, United Nation Environment Programme, (2017)

11. http://jdih.menlh.go.id/pdf/ind/IND-PUU-1-2009UU\%20No.\%2032\%20Th\%202009_Combine.pdf

12. Op.cit. Roraima.

13. Intelligence Project on Environmental Crime, Report on Environmental Crime in Europe, IPEC, Hague, (2015)

14. Caless, Bryn, Policing, 9, 3, https://doi.org/10.1093/police/pau059 (2015)

15. I. Martin, BJS 553 (2004)

16. Millie, Andrew. 'Reassurance Policing and Signal Crimes', in G. Bruinsma snd D. Weisburd (eds.) Encyclopedia of Criminology and Criminal Justice, (Springer : New York, 2014)

17. I. Martin, N. Fielding, From Community to Communicative Policing: Signal crimes and The Problem of Public Reassurance. Social, Res Online 7, 2 (2002) Available at: www.socresonline.org.uk 
18. J. Roach, R. Alexander, K. Pease, Policing, 85, 2 DOI: 10.1350/pojo.2012.85.2.574 (2012)

19. I. Martin I. Hellen, Signal Crimes, Social Reactions, and the Future of Environmental Criminology, (The Oxford Handbook of Environmental Criminology Edited by Gerben J.N. Bruinsma and Shane D. Johnson, DOI: 10.1093/oxfordhb/9780190279707.013.11 2018)

20. D. McQuail, Mass communication: An Introduction. (3rd edition). Thousand Oaks, (CA: Sage, 1994)

21. https://www.vebma.com/opini/pembangunan-proyek-pembangkit-listrik-tenaga-panasbumi-di-gunung-slamet/16706\#ixzz5MXbgDKKv

22. https://tekno.kompas.com/read/2012/10/12/10295762/_investor.pltp.baturraden .kantongi.izin.kemenhut

23. http://wartahijau.com/read/pembangunan-pltp-meningkatkan-risiko-bencana.

24. http://independen.id/read/peristiwa/256/pencemaran-lingkungan-pltp-lereng-slamet/

25. http://kopi-backpacker.blogspot.com/2017/07/dampak-mengerikan-dari-pltpgunung.html

26. https://banyumasnews.com/98224/banjir-bandang-landa-banyumas-dampak-proyekpltp-baturraden/

27. http://www.suarakarya.id/detail/50659/Proyek-PLTP-Baturaden-Ancam-LingkunganHidup-Seputar-Gunung-Slamet

28. https://www.melung.desa.id/adakah-dampak-lingkungan-di-wilayah-kami/

29. https://www.mapalaptm.com/berita-1599-peringati-hari-bumi-ratusan-pelajar-mahasiswa-menolak-proyek-pemerintah-pltp-di-gunung-slamet.html

30. https://purwokertokita.com/lingkungan/suara-suara-penolakan-pltp-di-gunungslamet.php https://www.change.org/p/pak-jokowi-cabut-izin-pltp-baturaden

31. https://www.pewartanusantara.com/aliansi-petani-indonesia-proyek-pltp-ancam-petanilereng-gunung-slamet/

32. https://regional.kompas.com/read/2017/07/18/15165611/tolak-pembangkit-listrikpanas-bumi-massa-duduki-gedung-dprd-banyumas.

33. https://www.hetanews.com/article/100966/ratusan-demonstran-tuntut-bupati-banyumascabut-izin-pltp-baturraden

34. https://www.gatra.com/rubrik/nasional/pemerintahan-daerah/289305-ratusan-wargalereng-selatan-gunung-slamet-demo-tuntut-ijin-pltp-dicabut

35. http://buruh.co/polisi-lakukan-kekerasan-pada-aksi-selamatkan-gunung-slamet/

36. https://www.republika.co.id/berita/nasional/hukum/17/10/10/oxlkz2318-pwi-proseshukum-pelaku-kekerasan-jurnalis-banyumas

37. https://www.kabargayo.com/aji-kota-purwokerto-kecam-kekerasan-pembubaran-paksademo-tolak-pltp-baturraden

38. Eriyanto, Analisis Naratif: Dasar-dasar dan Penerapannya dalam Anallisis Teks Berita Media, (Kencana, Jakarta, 2013) 